\title{
PRODUKSI PERHIASAN BERTEMAKAN FAUNA ENDEMIK INDONESIA SEBAGAI SARANA EDUKASI MASYARAKAT
}

Sza Sza Anggun¹ (yokichai@yahoo.com, Jurusan Kriya, Fakultas Seni Rupa, Institut Seni Indonesia Yogyakarta)

\begin{abstract}
The lack of information circulation about Indonesia's endemic fauna in the community, especially regarding the condition of its population in the wild, is one of the causes of the declining population of Indonesia's endemic fauna. There are still many people who capture and trade without knowing that some of them are on the verge of extinction. The business offers a creative solution to this problem by creating jewelry products that take Indonesian endemic fauna as a visual idea. Educative product marketing is expected to be able to provide information about fauna endemic to the community as well as being a characteristic/identity that distinguishes this business brand from other jewelry businesses. The implementation of this business program is broadly carried out in two stages, namely the production stage and the marketing stage. The production stage consists of exploration of idea, product design, and product realization. After entering the final stage of production, the marketing stage of this business will then begin. The marketing stage begins with planning and carrying out business branding, designing marketing facilities and packaging, and conducting promotions online and offline to the target market. The beauty of this jewelry product is expected to arouse the interest of the community to love and get to know more about Indonesia's endemic fauna species, while also meeting the people's need for quality Indonesian-made product.

Keywords: fauna, endemic, jewelry, educative
\end{abstract}

\section{ABSTRAK}

Kurangnya peredaran informasi seputar fauna endemik Indonesia di masyarakat, terutama mengenai keadaan populasinya di alam bebas, merupakan salah satu penyebab menurunnya populasi sebagian fauna endemik Indonesia. Masih banyak masyarakat yang menangkap dan memperjualbelikan fauna endemik tanpa mengetahui bahwa sebagian dari mereka sudah berada di ambang kepunahan. Usaha ini menawarkan sebuah solusi kreatif untuk masalah tersebut dengan menciptakan produk perhiasan yang mengambil fauna endemik Indonesia sebagai ide visualnya. Pemasaran produk yang dilakukan secara edukatif diharapkan dapat memberikan informasi seputar fauna endemik kepada masyarakat sekaligus menjadi sebuah ciri khas/identitas yang membedakan brand usaha ini dengan usaha perhiasan lainnya.Pelaksanaan program usaha ini secara garis besar dilakukan dalam dua tahap, yaitu tahap produksi dan tahap pemasaran. Tahap produksi terdiri atas eksplorasi ide, perancangan produk, dan pewujudan produk. Setelah memasuki tahap akhir produksi, tahap pemasaran usaha ini kemudian mulai dijalankan. Tahapan pemasaran dimulai dengan merencanakan dan melakukan branding usaha, mendesain sarana-sarana pemasaran dan packaging, serta melakukan promosi secara online dan offline kepada target pasar yang dituju. Keindahan dari produk perhiasan ini nantinya diharapkan menggugah minat masyarakat untuk mencintai dan mengenal lebih dalam lagi mengenai spesies fauna endemik Indonesia, sekaligus juga memenuhi kebutuhan masyarakat akan produk buatan Indonesia yang berkualitas.

Kata Kunci: fauna, endemik, perhiasan, edukatif 


\section{PENDAHULUAN}

Indonesia adalah salah satu negara kepulauan yang memiliki begitu banyak kekayaan alam di dalamnya. Salah satu dari kekayaan alam tersebut berupa banyaknya spesies fauna endemik yang tersebar di setiap pulau. Masing-masing dari fauna endemik tersebut mempunyai ciri khas yang amat menarik, seperti bentuk tanduk yang unik atau warna bulu yang eksotis. Namun sayangnya, karena keindahan dari berbagai fauna endemik tersebut, banyak orang yang menangkap mereka untuk dikoleksi dan diperjualbelikan tanpa menyadari bahwa populasi dari sebagian fauna tersebut di alam bebas sudah semakin memprihatinkan jumlahnya. Kenyataan ini menunjukkan bahwa pengetahuan masyarakat tentang status dan populasi berbagai fauna endemik masih cukup rendah. Hal tersebut juga dipicu oleh kurangnya peredaran informasi konkret seputar fauna endemik Indonesia di antara masyarakat.

Maka dari itu sebagai langkah awal mengatasi masalah tersebut, akhirnya terwujudlah inisiatif untuk memproduksi perhiasan bertemakan fauna endemik Indonesia, dengan harapan bahwa ketika dipasarkan kepada masyarakat dengan teknik pemasaran yang edukatif, produk perhiasan ini akan menjadi salah satu sarana edukasi tentang fauna endemik Indonesia. Keindahan dari produk perhiasan ini diharapkan menggugah minat masyarakat untuk mencintai dan mengenal lebih dalam lagi mengenai spesies fauna endemik Indonesia, sekaligus juga memenuhi kebutuhan masyarakat akan produk buatan Indonesia yang berkualitas.

\section{Karya Seni Perhiasan sebagai Sarana Edukasi Masyarakat}

Edukasi atau pendidikan pada dasarnya merupakan proses mendewasakan manusia, mengubah sikap atau tata laku manusia agar mencapai kedewasaan pikiran/pandangan terhadap berbagai subjek melalui bermacam-macam cara dan upaya. Dalam sebuah proses edukasi, agar dapat berjalan dengan efektif dibutuhkan suatu ketertarikan/minat dari diri manusia untuk mencari tahu dan mengeksplorasi suatu subjek atau bidang. Untuk memunculkan perasaan ketertarikan terhadap suatu hal dalam diri manusia (interest) secara sengaja, diperlukan suatu stimulus yang dapat memengaruhi pikiran manusia. Pada situasi inilah karya seni (rupa) dalam wujud perhiasan dapat berperan sebagai stimulus visual yang cukup kuat bagi manusia. Hal ini sebagaimana dengan pendapat filsuf seni berkebangsaan Amerika, Thomas Munro, bahwa seni adalah alat buatan manusia untuk menimbulkan efek-efek psikologis atas manusia lain yang melihatnya. Efek-efek tersebut mencakup segala tanggapan yang berwujud pengamatan, pengenalan, imajinasi, baik yang rasional maupun irasional (Munro dalam Yoyok, 2006: 2). Hal ini juga seturut dengan pengertian seni menurut Ki Hajar Dewantara, yakni bahwa seni adalah suatu perbuatan yang timbul dari perasaan manusia dan bersifat indah, sehingga mampu menggerakkan jiwa (Yoyok, 2006: 2).

Untuk memenuhi kebutuhan di atas, penciptaan karya seni perlu diorientasikan agar menghasilkan karya dengan fungsi sosial sebagai fungsi utamanya. Suatu karya seni dianggap menjalankan suatu fungsi sosial apabila:

1. Karya tersebut cenderung memengaruhi perilaku kolektif manusia;

2. Karya tersebut diciptakan terutama untuk dilihat atau digunakan dalam keadaan publik; dan

3. Karya tersebut mengekspresikan atau mendeskripsikan aspek sosial atau aspek 
kolektif dari suatu hal/eksistensi (Feldman, 1967: 36).

Dengan kata lain, karya seni yang dibutuhkan dalam konteks ini ialah karya yang dapat memengaruhi perilaku manusia secara berkelompok, yang kemudian menimbulkan efek pada pikiran, perasaan, serta tindakan yang mereka lakukan. Pemilihan perhiasan sebagai bentuk produk/karya merupakan hasil pertimbangan agar masyarakat dapat lebih mudah tertarik dan menikmati karya ini. Hal ini mengingat bahwa perhiasan merupakan benda yang familier bagi masyarakat awam yang bukan pemerhati seni sekalipun.

Apabila karya seni perhiasan telah berhasil membangkitkan ketertarikan manusia terhadap suatu subjek, langkah berikutnya dalam proses edukasi ini ialah penyampaian materi seputar subjek tersebut. Aspek publikasi dalam pemasaran produk/karya dapat dimanfaatkan untuk menyampaikan materi/informasi edukatif yang tidak dapat tersampaikan oleh karya seni semata. Dalam kegiatan produksi karya perhiasan ini, publikasi pemasaran berupa konten media sosial (Instagram) dan bonus pembelian produk berupa kartu edukasi diisi informasi verbal yang dapat menunjang proses edukasi kepada masyarakat umum. Display produk yang menarik dan selaras dengan tema dan tujuan produk dapat menjadi salah satu faktor penunjang keberhasilan dalam menjadikan suatu karya perhiasan sebagai sarana edukasi.

\section{Gambaran Umum Rencana Usaha}

Berikut gambaran umum mengenai rencana usaha produksi perhiasan ini.

\section{A. Survei Pasar dan Kompetitor}

Masyarakat Indonesia terutama pada kalangan ekonomi menengah umumnya menginginkan sebuah produk yang berkualitas namun terjangkau. Hal ini juga sesuai dengan survei sederhana yang dilakukan tim penulis kepada teman-teman dan kerabat di sekitar yang memenuhi kriteria target pemasaran untuk produk usaha ini (perempuan dan laki-laki Indonesia dengan kisaran usia 25-40 tahun atau usia produktif, dengan kemampuan finansial menengah dan ke atas). Survei tersebut membuktikan bahwa rata-rata responden menginginkan suatu produk perhiasan yang berkarakter, berkualitas, dan tidak pasaran.

Sejauh ini tim penulis belum menemukan adanya usaha perhiasan sejenis/kompetitor yang mengkhususkan diri untuk membuat perhiasan dengan tema fauna endemik Indonesia. Tim penulis juga belum banyak menemukan usaha perhiasan yang berani menggunakan material-material yang tidak lazim untuk perhiasan, seperti plastik, logam, dan akrilik dengan gaya kontemporer, sehingga usaha ini memiliki peluang yang cukup baik untuk berkembang.

\section{B. Keunggulan Komoditas Usaha}

Sumber ide yang melimpah (banyaknya ragam fauna endemik Indonesia) membuka banyak peluang untuk berinovasi dalam desain produk, dan kekhususan tema dari produk usaha perhiasan ini juga menjadi kekuatan utama dalam pemasaran produk kepada masyarakat. Tim penulis memilih bahan baku produk yang cukup unik untuk produksi perhiasan, yakni plastik, akrilik, dan bermacam-macam logam, guna menciptakan produk perhiasan yang unik, berkualitas, namun tetap terjangkau oleh target pasar. Produk-produk perhiasan yang dihasilkan usaha ini juga mendukung kelestarian lingkungan dengan menggunakan bahan yang dapat didaur ulang, seperti logam dan juga plastik PLA yang bersumber dari bahan organik, serta menggunakan bahan baku kertas untuk packagingnya. 


\section{METODE PELAKSANAAN}

Metode pelaksaanan usaha produksi perhiasan ini secara garis besar terdiri atas dua bagian, yakni aspek produksi dan manajemen usaha.

\section{A. Aspek Produksi}

Aspek produksi dalam usaha ini meliputi beberapa tahap, yaitu:

1. Tahap Eksplorasi

Untuk koleksi pertama dari perhiasan yang diproduksi, tim penulis mengamati burung Jalak Bali (tema koleksi perhiasan pertama usaha ini) untuk mendapatkan karakteristik dari burung tersebut. Hasil dari penjelajahan atau analisis data ini kemudian dijadikan dasar untuk membuat rancangan atau desain.

2. Tahap Perancangan

Pada tahap ini, hasil dari penjelajahan atau analisis data referensi divisualisasikan ke dalam berbagai alternatif desain (sketsa). Kemudian ditentukan rancangan/sketsa terpilih yang akan dijadikan acuan dalam pembuatan rancangan final berbentuk bagan teknik (technical drawing). Bagan teknik ini dibuat dengan program CAD, yaitu CorelDraw $\mathrm{X} 7$ untuk gambar 2D dan Rhinoceros 4.0+Matrix 6.0 untuk gambar 3D. Bagan teknik (proyeksi, potongan, detail, perspektif) ini kemudian dijadikan acuan dalam proses perwujudan produk.

3. Tahap Pewujudan

Pada tahap ini, tim bagian produksi mulai mengerjakan produk sesuai bagan teknik. Pengerjaan produk dimulai dengan pembuatan bagian-bagian perhiasan per material. Bagian perhiasan berbahan plastik diproduksi menggunakan metode $3 D$ printing, kemudian dikikir, dan diamplas sampai halus. Untuk bagian perhiasan berbahan akrilik, produksi dilakukan dengan cara memotong lembaran aklirik menggunakan mesin laser cutting. Untuk bagian perhiasan dengan bahan logam, produksi dilakukan dengan mengolah plat logam secara manual menggunakan alat pertukangan logam, seperti tatah logam, gergaji perhiasan, kikir logam, dan alat pembakar logam. Setelah semua bagian selesai diproduksi, kemudian dilanjutkan dengan tahap assembling produk. Bagian-bagian produk yang terpisah disatukan hingga kemudian menjadi produk perhiasan yang utuh dan siap dikemas/dipasarkan.

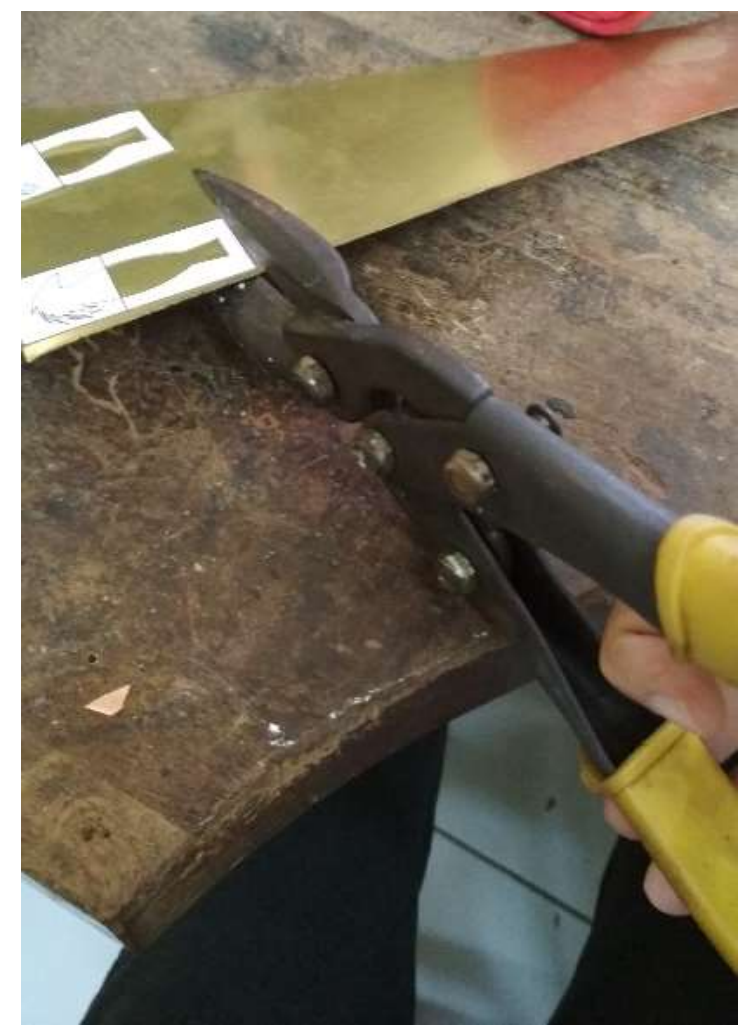

Gambar 1. Proses Produksi Perhiasan (Pemotongan Plat Logam)

(Sumber Foto: Sza Sza Anggun, 2018)

\section{B. Manajemen Usaha}

Manajemen usaha ini meliputi beberapa kegiatan, yaitu:

1. Membuat brand image untuk usaha ini dengan menentukan citra yang ingin dikomunikasikan terhadap target pasar mengenai usaha ini beserta produknya. 
2. Melakukan branding usaha dengan menentukan nama (merek) usaha, desain logo, dan palet warna utama untuk identitas brand.

3. Mendesain dan membuat sarana-sarana pemasaran menggunakan identitas brand yang telah dibuat, baik sarana pemasaran online (website, konten media sosial), maupun sarana pemasaran langsung (brosur, kartu nama, packaging produk, educational card).

4. Melakukan perhitungan harga (pricing) untuk menentukan harga jual produk.

5. Setelah sarana-sarana pemasaran telah selesai disiapkan, mulai dilakukan promosi dan pemasaran produk secara online dan offline kepada target pasar yang dituju secara berkala.

6. Memastikan pembeli produk mendapatkan produk beserta educational card yang sudah dikemas dalam packaging yang telah didesain oleh anggota tim desain dan pemasaran dalam keadaan baik.

7. Mengumpulkan setiap respon dan masukan dari konsumen maupun calon konsumen untuk acuan perbaikan dalam manajemen usaha.

\section{Hasil yang Dicapai dan Potensi Pengembangan Usaha}

Berikut ini rincian hasil yang telah dicapai usaha produksi perhiasan ini hingga sekarang, serta potensi pengembangannya di masa mendatang.
1. Hasil Produksi

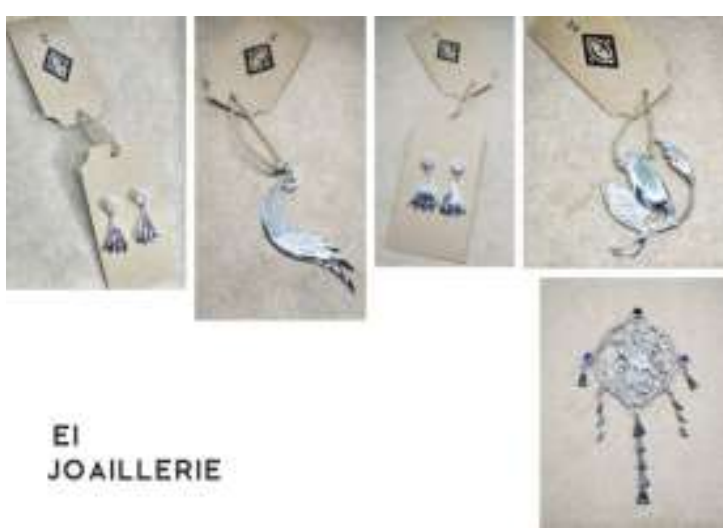

Gambar 2. Foto Produk 1

(Sumber Foto: Sza Sza Anggun, 2018)

Hingga saat ini, terdapat berbagai jenis produk perhiasan yang telah dihasilkan. Koleksi perhiasan perdana yang dihasilkan oleh usaha ini mengambil tema "Burung Jalak Bali", yang merupakan burung endemik Indonesia dari Pulau Bali. Produk-produk tersebut terdiri atas anting, earcuff, liontin, bros, gantungan kunci, dan hairpiece. Produkproduk tersebut terbuat dari sterling silver (perak kadar 92, 5\%), tembaga, kuningan, plastik PLA, dan akrilik. Berikut beberapa contoh foto produk yang telah selesai diproduksi. 


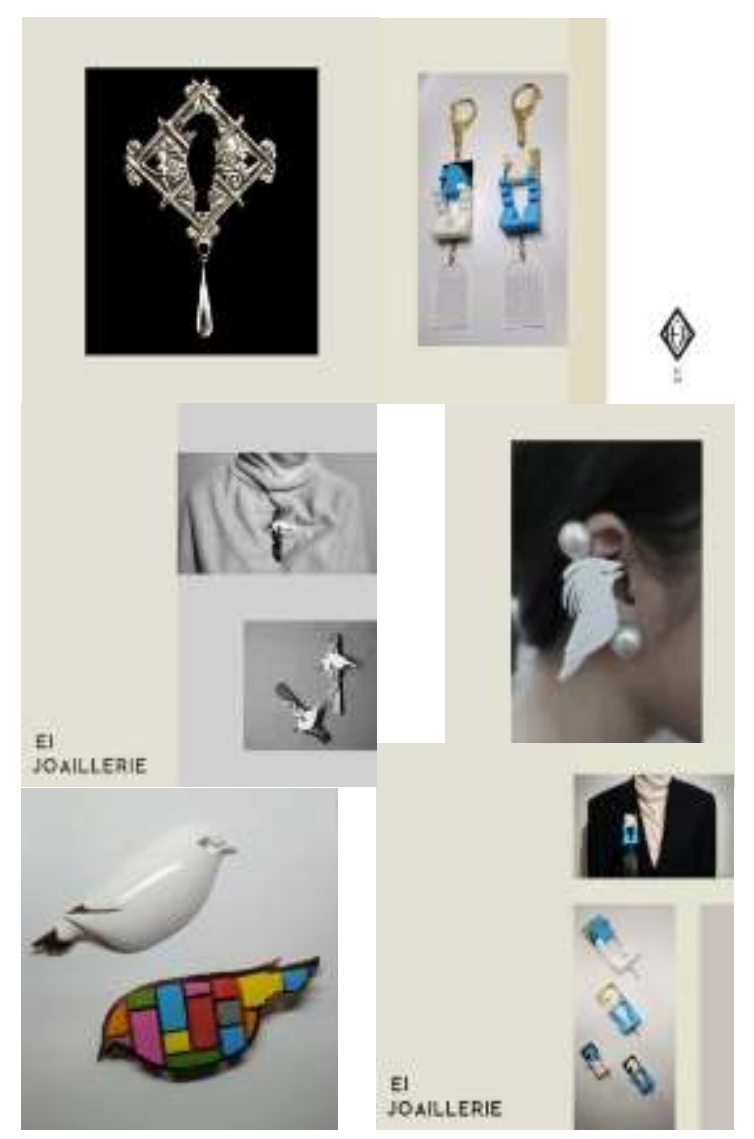

Gambar 3. Foto Produk 2

(Sumber Foto: Sza Sza Anggun, 2018)

2. Hasil Pemasaran dan Penjualan

Hasil pemasaran dan penjualan dari produk yang dihasilkan oleh kegiatan usaha ini ialah sebagai berikut.

\section{a. Branding}

Produk perhiasan yang dihasilkan usaha ini dipasarkan dengan merek EI JOAILLERIE (EIJO), yang merupakan akronim dari Endemik Indonesia Joaillerie. Berikut logo dan kelengkapan branding dari merek tersebut:
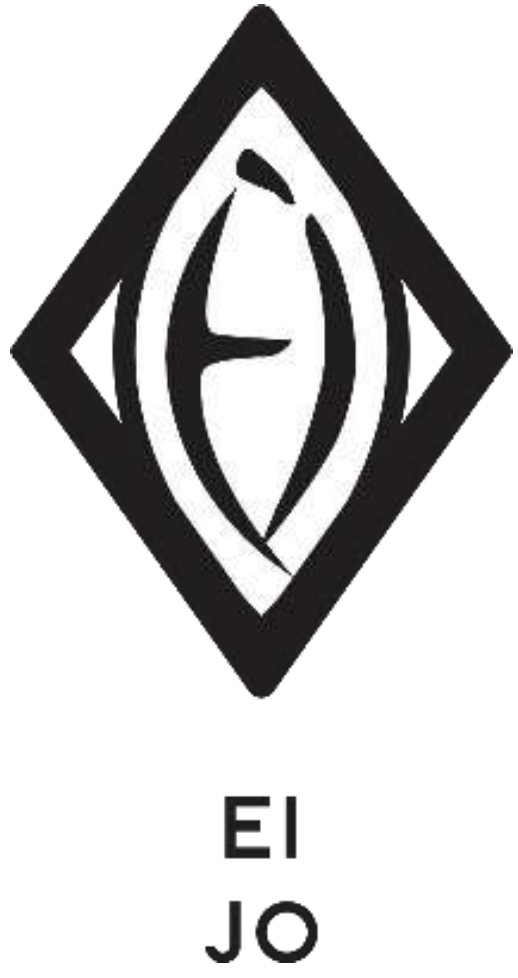

Gambar 4. Logo Usaha

(Sumber Foto: Sza Sza Anggun, 2018)

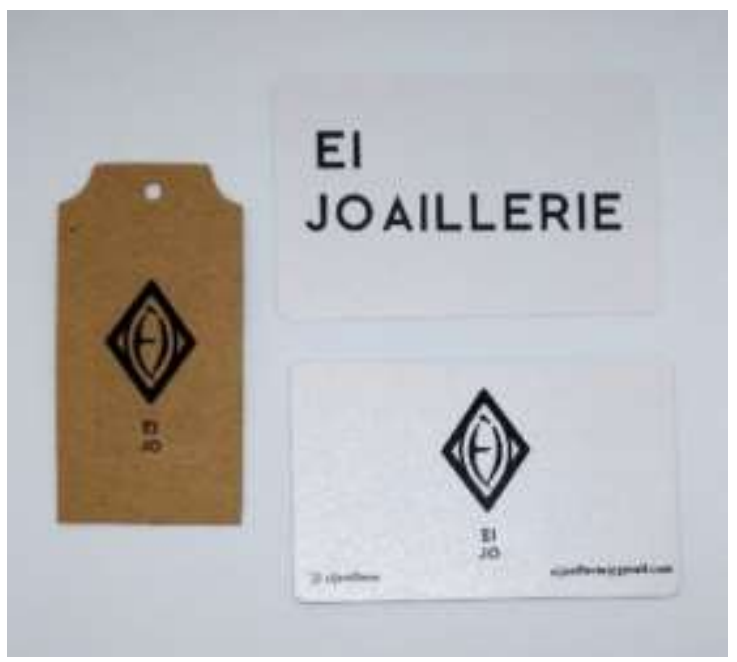

Gambar 5. Kelengkapan Branding Usaha (Sumber Foto: Sza Sza Anggun, 2018)

b. Promosi

Promosi produk perhiasan usaha ini telah dilakukan secara online dan offline. Promosi produk secara offline yang sudah dilakukan yaitu melalui partisipasi pada gelar produk di acara Raker dan Buka Bersama Keluarga 
Jepara Yogyakarta pada tanggal 1 Juni 2018, kemudian pada acara gelar produk PKM dan KBMI yang dilaksanakan di lobby rektorat Institut Seni Indonesia Yogyakarta pada tanggal 13 Juli 2018, serta promosi dari mulut ke mulut melalui jaringan relasi tim penulis. Promosi produk secara online dilakukan melalui Instagram dalam akun @eijoaillerie.

c. Pricing

Harga setiap produk perhiasan berbeda-beda, menyesuaikan jumlah bahan baku yang dibutuhkan. Kalkulasi harga jual produk adalah sebagai berikut:

Biaya bahan baku + biaya alat, branding, dan packaging (per produk) + biaya pengerjaan (sama dengan biaya bahan baku) + target keuntungan $20 \%+$ cetak kartu edukasi $=$ harga jual.

Keterangan:

- Biaya alat, branding, dan packaging (biaya $A B P$ ) per produk = total biaya $A B P$ dibagi dengan jumlah produk (asumsi produksi awal sebanyak 40 pieces). Berikut adalah perhitungan $A B P$ per tanggal 20 Mei 2018.

- Biaya $\mathrm{ABP}$ per produk = Total Biaya ABP : Jumlah produk $=$ Rp. $808.450: 40=$ Rp. 20.211 dibulatkan menjadi Rp.21.000

- Asumsi biaya cetak kartu edukasi adalah sebesar Rp. 10.000

Berikut contoh kalkulasi harga jual untuk salah satu produk usaha ini
Tabel 1. Kalkulasi Harga Jalak Bali stud earrings

\begin{tabular}{|l|c|c|}
\hline \multicolumn{1}{|c|}{ Rincian } & \multicolumn{1}{c|}{ Unit } & Total \\
\hline Biaya bahan & 1 produk & 50.000 \\
\hline Biaya Pengerjaan & 1 produk & 50.000 \\
\hline $\begin{array}{l}\text { Biaya alat, } \\
\text { branding, dan } \\
\text { packaging (per } \\
\text { produk) }\end{array}$ & 1 produk & 21.000 \\
\hline $\begin{array}{l}\text { Target keuntungan } \\
\text { 20\% }\end{array}$ & 1 produk & 24.200 \\
\hline $\begin{array}{l}\text { Cetak kartu } \\
\text { edukasi }\end{array}$ & 1 buah & 10.000 \\
\hline Total Harga Jual & Pembulatan & 155.000 \\
\hline
\end{tabular}

d. Packaging dan Kartu Edukasi

Packaging produk perhiasan ini berbahan dasar kertas brown kraft dengan tambahan stiker logo, untuk meminimalkan pemakaian plastik. Setiap pelanggan yang membeli produk perhiasan EIJO akan mendapatkan satu set kartu edukasi yang berisi ilustrasi dan informasi edukatif seputar hewan endemik Indonesia. Kartu edukasi ini juga dapat berfungsi sebagai pembatas buku.

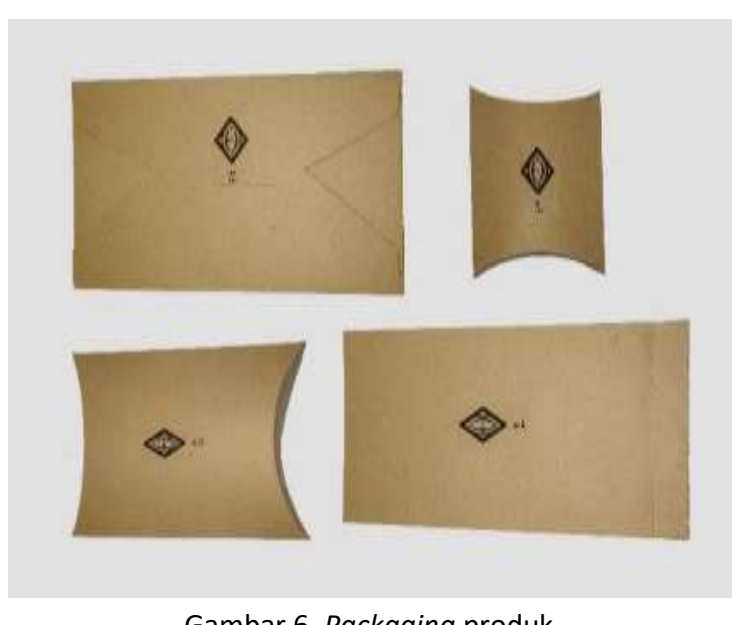

Gambar 6. Packaging produk 

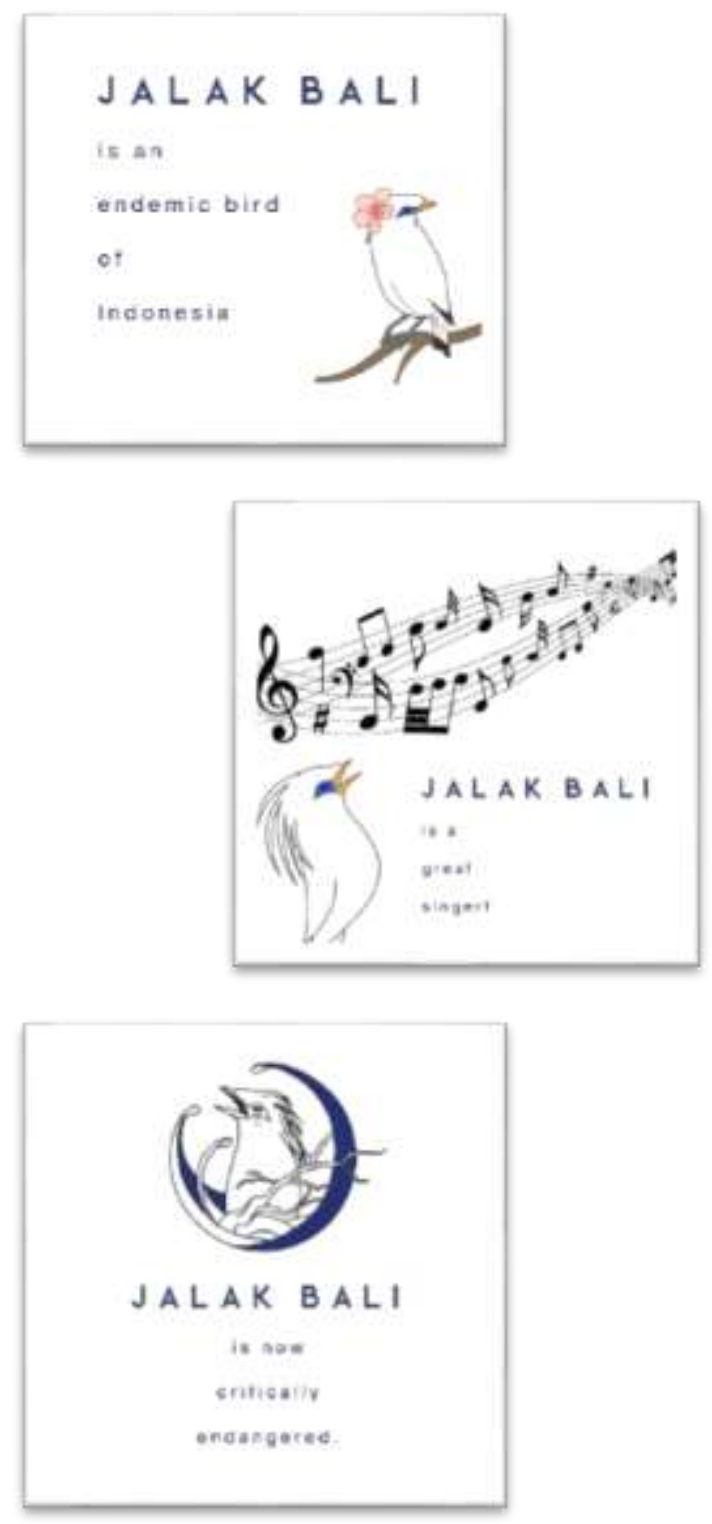

(Sumber Foto: Sza Sza Anggun, 2018)

Gambar 7. Kartu Edukasi

(Sumber Foto: Sza Sza Anggun, 2018)

e. Penjualan

Produk perhiasan yang telah terjual hingga pada saat artikel ini disusun (1 Juni 2018 - 28 Juli 2018), telah mencapai 16 buah produk, dengan total penjualan sebesar Rp. 1.958.000. Persentase pencapaian menuju BEP pada saat ini yaitu sebesar $66 \%$ (rincian analisis pencapaian BEP dapat dilihat pada lampiran 3). Diperkirakan total waktu yang dibutuhkan untuk mencapai BEP dari awal penjualan (1 Juni 2018) yakni kurang lebih 3 bulan jika penjualan stabil, dengan asumsi pencapaian per bulannya sebesar $33 \%$.

3. Potensi Pengembangan Usaha

Potensi pengembangan usaha produksi perhiasan ini adalah sebagai berikut:

a. Potensi peningkatan produksi melalui kerja sama dengan mitra di bidang manufaktur perhiasan,

b. Potensi peningkatan penjualan produk dengan memanfaatkan lebih banyak platform penjualan, seperti online marketplace.

c. Potensi diversifikasi produk ke jenis aksesoris lain selain perhiasan, seperti tas dan dompet.

\section{PENUTUP}

Rancangan atau komposisi desain perhiasan bergaya kontemporer akhirnya menjadi pilihan yang dirasa paling tepat untuk menarik minat masyarakat untuk mengenal lebih lanjut seputar fauna endemik Indonesia, karena gaya perhiasan kontemporer cenderung lebih variatif dari segi desain, material, dan teknik, sehingga menghasilkan perhiasan yang unik, tidak pasaran, dan menarik bagi masyarakat. Teknik pembuatan dan material yang cukup variatif, seperti penggunaan teknik tatah logam, 3D printing dan laser cutting, serta penggunaan material, seperti logam, plastik dan akrilik menjadi pilihan yang tepat untuk proses produksi perhiasan usaha ini, setelah mempertimbangkan segi kualitas dan kesesuaian hasil produksi dengan rancangan awal perhiasan.

Strategi pemasaran yang tepat bagi usaha ini agar dapat terus berkembang dan berkelanjutan di masa mendatang, yaitu dengan gencar mempromosikan produk secara online (terutama melalui media sosial) 
dan offline (melalui gelar produk dan bazaar) kepada target pasar yang dituju. Akan tetapi, seluruh bentuk pemasaran yang dilakukan harus tetap berpegang pada konsep awal brand yang telah dibangun, yakni brand perhiasan dengan tema edukatif seputar fauna endemik Indonesia.

\section{DAFTAR PUSTAKA}

Badan Pengembangan dan Pembinaan Bahasa. 2016. Kamus Besar Bahasa Indonesia [online]. Diakses pada 20 Maret 2017 di URL: http://kbbi.web.id/didik

Feldman, Edmund Burke. 1967. Art as Image and Idea. New Jersey: Prentice-Hall.

Gustami, S. P. 2007. Butir-Butir Mutiara Estetika Timur: Ide Dasar Penciptaan Karya. Yogyakarta: Prasistwa.

Yoyok \& Siswandi. 2006. Pendidikan Seni Budaya kelas VII SMP. Jakarta: Yudistira. 